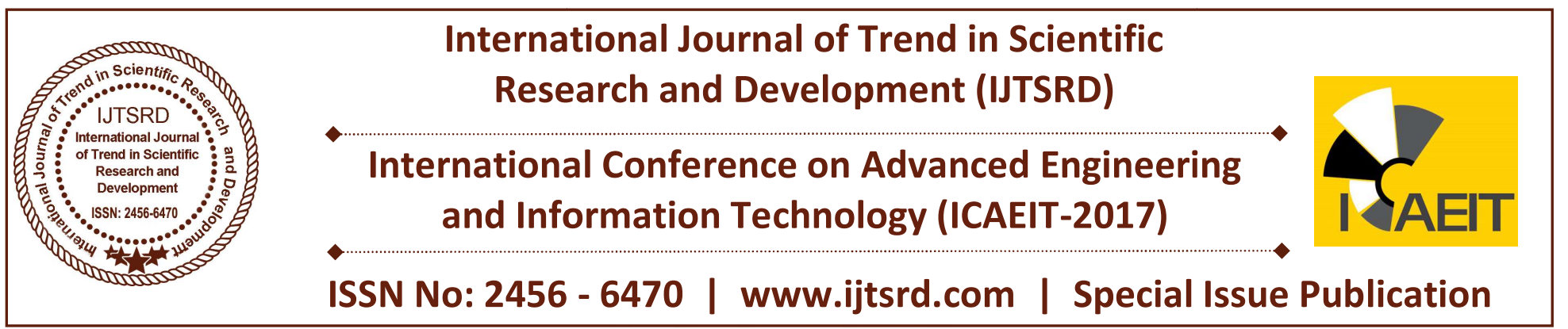

\title{
Desalination Approach of Seawater and Brackish Water by Coconut Shell Activated Carbon as a Natural Filter Method
}

\author{
Jayaprakash M C ${ }^{1}$, Poorvi Shetty ${ }^{1}$, Raju Aedla ${ }^{2}$, D V Reddy ${ }^{3}$ \\ ${ }^{1}$ Department of Civil Engineering, Mangalore Institute of Technology and Engineering, \\ BadagaMijar, Moodabidri, Karnataka, India \\ ${ }^{2}$ GSST, Kumamoto University, Kurokami, Kumamoto, Japan \\ ${ }^{3}$ Rtd. Professor\& Head, NITK, Surathkal; Consulting Faculty, L\&T-Ltd-Heavy Civil Infrastructure, \\ Hq- Chennai, Tamil Nadu, India
}

\section{ABSTRACT}

Engineers are challenged to develop cost effective ways to produce large quantities of water suitable for drinking, crop irrigation and commercial use for regions of the world that suffer from water shortages. Water desalination is expensive, requiring large amounts of energy and specialized equipment to convert saltwater into drinking water. The present study aims to develop a cheaper, cleaner, easy and more energy-efficient way of desalinating seawater technique by using natural filters, it can help the common people as it affordable during their immediate requirements. The developed technique seemed to be very effective in reducing the concentration of seawater ions. The desalination system is developed by selecting coconut-shell charcoal as the substrate material. As per the results obtained from prototype of seawater and brackish water, there is $60 \%$ reduction in chloride and $75 \%$ reduction in sodium; this is mainly due to the usage of activated carbon charcoal as the filter media. It is also observed through experiments that there is $100 \%$ reduction in iron, $53 \%$ reduction in sulphate, $20 \%$ reduction in total dissolved solids and $12 \%$ reduction in hardness which clearly indicates that the selected filter medias those are activated carbon charcoal, sand, laterite would be used as the filter medias for future experiments on desalination using natural filters.

This work is to present an overview of current and future technologies applied to the desalination of brackish as well as seawater to produce freshwater for supplementing drinking water supplies to the common people in smaller quantity. Removal efficiency increases with the increase in contact time respectively, for both seawater and brackish water, which was considered to be maximum purification $\sim 40 \%$.

Keywords: Desalination, Seawater/Brackish water, Activated Carbon, Coconut Charcoal, Eco-friendly.

\section{INTRODUCTION}

Fresh water today is a scarce resource, and it is being felt the world over. More than 2000 million people would live under conditions of high water stress by the year 2050, according to the UNEP (United Nations Environment Programme), which warns water could prove to be a limiting factor for development in a number of regions in the world. Around one-third of the world population now lives in countries with moderate to high water stress- where water consumption is more than $10 \%$ of the renewable fresh water supply, said the GEO (Global Environment Outlook) 2000, the UNEP's millennium report.

As population increase and source of high quality, fresh drinking water decrease, using desalination processes to provide freshwater when other sources and treatment procedures are uneconomical or not environmentally responsible is becoming more and 
more common. Desalination is any process that removes excess salts and other minerals from water. In most desalination processes, saltwater (also called "feed water") is treated and two streams of water are produced: 1. Treated freshwater that has low concentrations of salts and minerals. 2. Concentrate or brine, which has salt and mineral concentrations higher than that of the feed water.

Desalination processes may be used in municipal, industrial, or commercial applications. With improvements in technology, desalination processes are becoming cost-competitive with other methods of producing usable water for our growing needs. The pure water that is obtained after desalination must be re-mineralised to be adequate for human consumption. Desalination has been used for thousands of years - Greek sailors boiled water to evaporate fresh water away from the salt and Romans used clay filters to trap salt. Today's sophisticated methods still generally use the concepts of distillation or filtration.

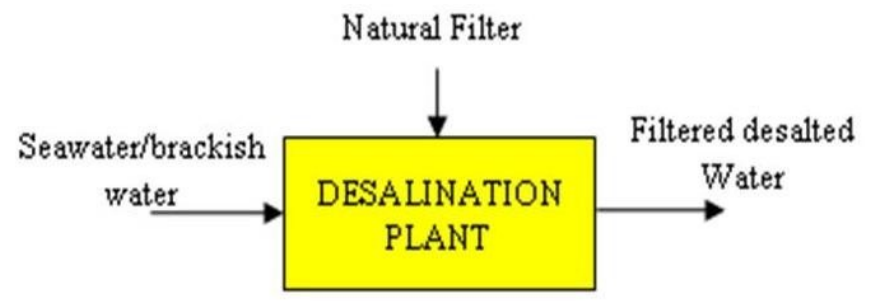

Fig.1 Main inputs and outputs in a desalination process

The feed water for desalination processes can be seawater or brackish water. Brackish water contains more salt than fresh water but less than saltwater. Brackish water is commonly found in estuaries, which are the lower courses of rivers where they meet the sea. Two technologies are primarily used around the world for desalination: thermal distillation and membranes. Both technologies need energy to operate and produce freshwater.

Right now, desalinating seawater is the only viable way to provide water to growing populations, and large desalination plants are now a fact of life in Egypt and other Middle Eastern countries. Most of these plants rely on a multi-step process based on reverse osmosis, which requires expensive infrastructure and large amounts of electricity. These plants release large quantities of highly concentrated salt water and other pollutants back into the seas and oceans as part of the desalination process, creating problems for marine environments.
Thus, the present work would make an attempt of using the traditional natural filter media to desalinate the seawater. This approach may help the common people to desalinate sea water on their own in affordable manner.

\subsection{Indian Scenario}

India has long coast line of nearly $7516.6 \mathrm{~km}$ along which several million people live and are engaged in various activities. Availability of fresh water has been the main centre of growth of civilization. However, there is lots of inequality existing on earth, which needs to be artificially corrected through incorporation of technologies. With the growth of world population the need of fresh water has also increased substantially which has resulted in growth of desalination installation as well. Logically the desalination activities are concentrated on those parts of the earth where availability of water is scares. This is precisely the reason why more than $80 \%$ of desalination plants are located in the water scares Middle East region. Unequal water distribution also exists within our country and fresh water desalination technology is getting concentrated more on water scares areas. Besides producing desalted water for human consumption and Industrial requirement these technologies are also found to be advantageous in the recovery of water from waste streams. There is no reliable statistics available on number of plants, their capacities, technologies adopted and status on these plants in India. However, rough indications are that there are more than 1000 membrane based desalination plants of various capacities ranging from $20 \mathrm{~m} 3 /$ day to $10,000 \mathrm{~m} 3 /$ day.

The "best" desalination system should be more than economically reasonable in the study stage. It should work when it is installed and continue to work and deliver suitable amounts of fresh water at the expected quantity, quality, and cost for the life of a project. Engineers are challenged to develop cost effective ways to produce large quantities of water suitable for drinking and crop irrigation for regions of the world that suffer from water shortages. Water desalination is expensive, requiring large amounts of energy and specialized equipment to convert saltwater into drinking water.

\section{Objectives}

The objective of this work is to present an overview of current and future technologies applied to the desalination of brackish and seawater to produce 
freshwater for supplementing drinking water supplies to the common people in smaller quantity.

Desalination of seawater using natural filters can help the common people as it affordable during their immediate requirements.

Race is on to find a cheaper, cleaner and more energyefficient way of desalinating seawater.

\section{The other objectives include:}

$>$ Irrigation (productive use)

$>$ Domestic uses

Urban and recreational uses

$>$ Aqua culture

$>$ Industrial Chiller

$>$ Fire extinguish

\subsection{Inspiration from available natural resources and processes Use of coconut shell charcoal for water purification}

Characteristics of coconut shell charcoal

$>100 \%$ organic

$>$ Renewable resource

$>$ High Calorific Heat Value

$>$ Environmental Friendly

$>$ Ready available especially in coastal areas

\section{Experimental Setup}

Preparation of Coconut Shell Charcoal

Burn in open air

$50-60$ whole shells $1 \mathrm{~kg}$ of charcoal

Sieve size : $2.36 \mathrm{~mm}-4.75 \mathrm{~mm}$

Through washing; drying

Procurement of other naturally available materials

Fine aggregate: (Sieve size $2.36 \mathrm{~mm}$ to $4.75 \mathrm{~mm}$ )

Coarse Aggregate: $\sim 4 \mathrm{~mm}$ to $10 \mathrm{~mm}$

Laterite Pebbles: $\sim 4 \mathrm{~mm}$ to $10 \mathrm{~mm}$

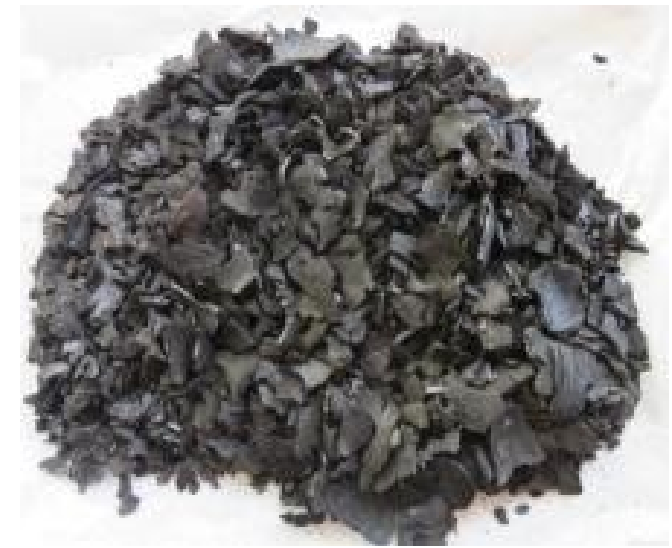

Coconut Charcoal $5 \mathrm{~mm}$

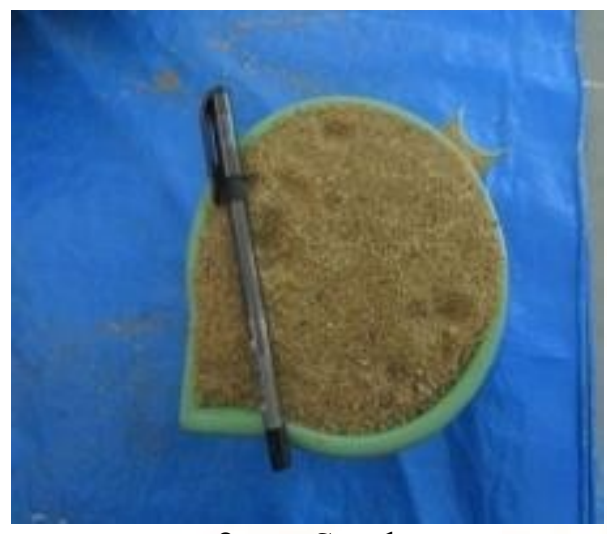

$2 \mathrm{~mm}$ Sand

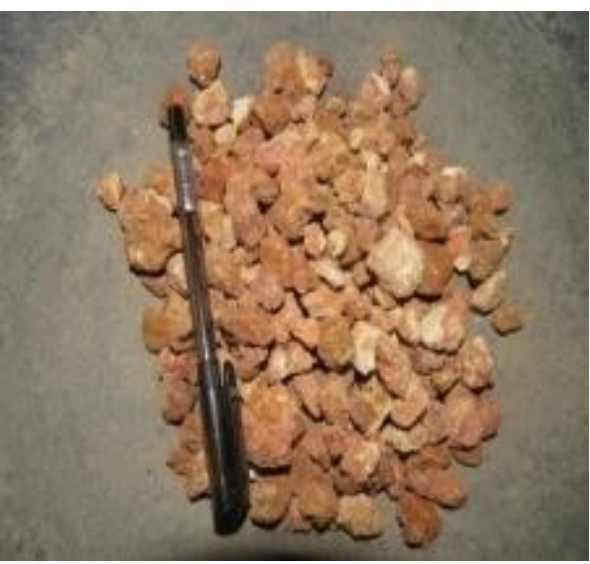

Laterite $\sim 5 \mathrm{~mm}$

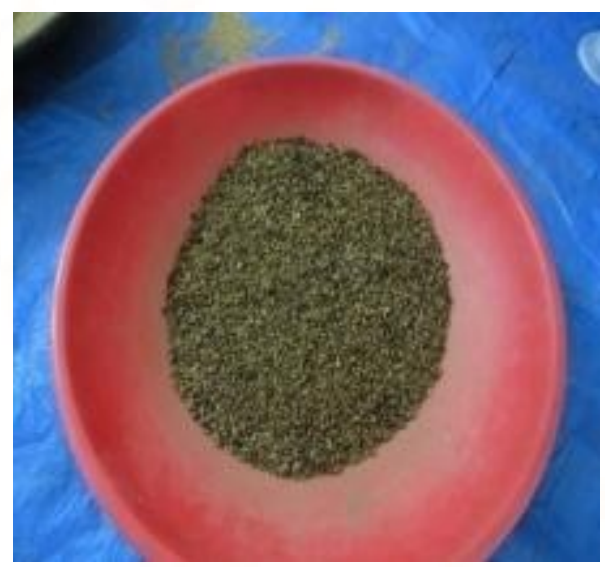

$4 \mathrm{~mm}$ Sand

Fig.2 Natural Filter Materials

\subsection{Charcoal Based Desalination Prototype}

Desalination prototype were made using waste PET (polyethylene terephthalate) bottles as a outer cover to prepare the charcoal based prototype in different layers of filter materials. As an approach of preliminary observation FIVE prototypes are made for each seawater and brackish water separately with varying thickness, such that all five prototypes having different layer thickness of activated carbon coconut charcoal along with other natural filter materials to observe the appreciable result. 
PET bottles has been used to make the prototype in the present work these bottles were inverted and the bottom portion is cut as the water is to be poured from the top. The top portion is kept open as the atmospheric pressure can act over it and it helps in the filtration process. Sand and gravels are used to filter out larger sediments present in the seawater where place top and bottom portion of the prototype, coconut charcoal placed in between the sand filters.
The fine aggregates in the top layer of the sand gradually forming a biological zone to filter out bacteria, viruses and parasites. Then the feed water reaches the surface of coconut shell charcoal. Coconut shell charcoal act as a activated carbon hold the salt ions utilizing as a chemical adsorption. Filtered cloth has been used at the end of the bottle neck to filter out the particulate contaminants and carbon and let the purified water through.

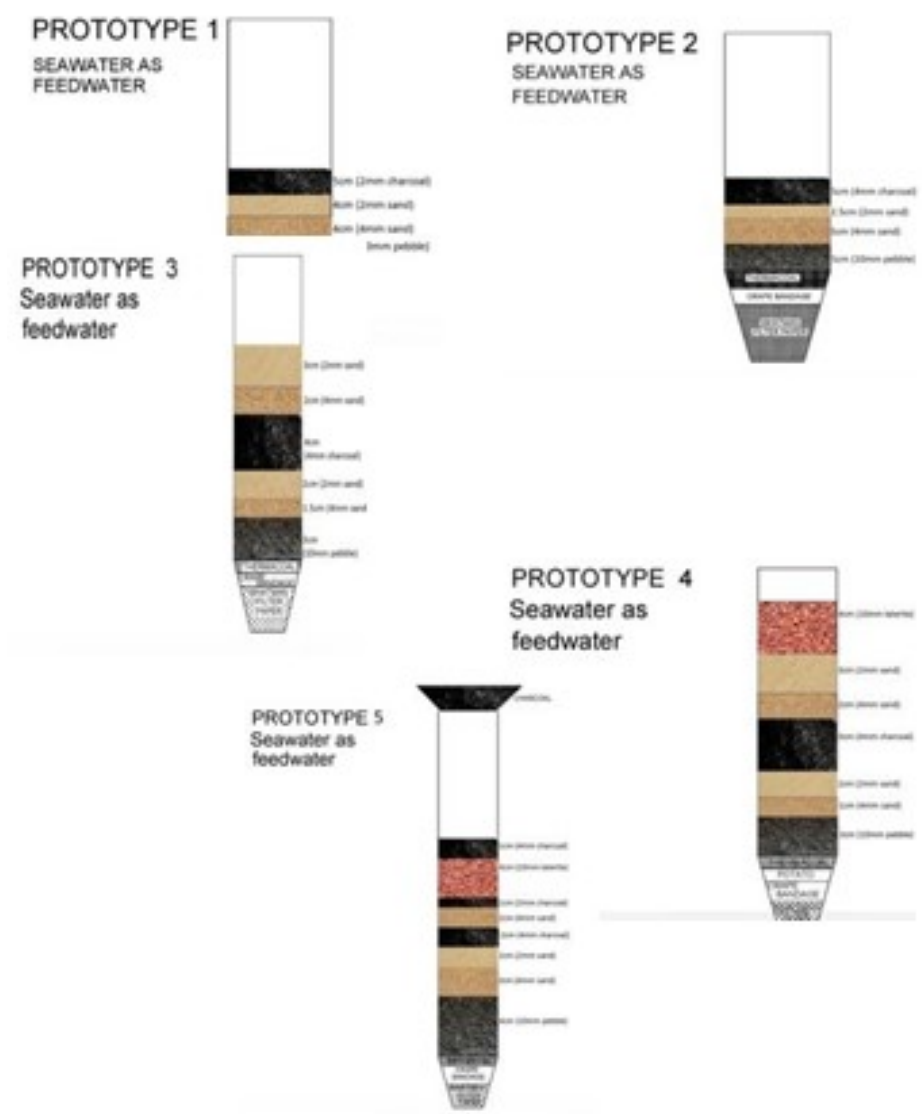

Fig.3 Prototypes prepared for desalination process for preliminary observation

\section{Results and Conclusion}

The natural filters especially coconut charcoal is better approach for the desalination process, around $30 \%$ of the saltwater ions reduced by the process is given the platform to continue the research to get better result.
Natural filter methods is the best approach in the view of

$>$ Ease of manufacture

$>$ Eco-friendly solution

$>$ Safe disposal/reuse of charcoal

$>$ Household Utility (esp. coastal/rural areas)

$>$ Cost effective solution

$>$ Energy efficient.

\begin{tabular}{|c|c|c|c|c|c|c|}
\hline $\begin{array}{c}\text { Chemical } \\
\text { ions }\end{array}$ & $\begin{array}{c}\text { Seawater } \\
\text { ions } \\
(\mathrm{mg} / \mathrm{l})\end{array}$ & $\begin{array}{c}\text { Reduction } \\
\text { concentration of } \\
\text { seawater ions } \\
(\mathrm{mg} / \mathrm{l})\end{array}$ & $\begin{array}{c}\text { Brackish } \\
\text { water } \\
\text { ions } \\
(\mathrm{mg} / \mathrm{l})\end{array}$ & $\begin{array}{c}\text { Reduction } \\
\text { concentration of } \\
\text { brackish water } \\
\text { ions }(\mathrm{mg} / \mathrm{l})\end{array}$ & $\begin{array}{c}\text { Reduction } \\
\text { percentage } \\
\text { in seawater } \\
(\%)\end{array}$ & $\begin{array}{c}\text { Reduction } \\
\text { percentage } \\
\text { in brackish } \\
\text { water }(\%)\end{array}$ \\
\hline Chloride & 17179.6 & 12335.134 & 7577.65 & 6849.3 & 28.19 & 9.6 \\
\hline Sodium & 10100 & 489.98 & 8291 & 465.7 & 76.44 & 78.9 \\
\hline Hardness & 6320 & 5860 & 3,220 & 2852 & 8 & 11.42 \\
\hline Iron & 14.5 & 0 & 11.1 & 0 & 100 & 100 \\
\hline
\end{tabular}


International Journal of Trend in Scientific Research and Development (IJTSRD) | ISSN: 2456-647

\begin{tabular}{|c|c|c|c|c|c|c|}
\hline Sulphate & 2830 & 812 & 1869 & 610 & 35.04 & 45.53 \\
\hline $\begin{array}{c}\text { Total } \\
\text { dissolved } \\
\text { solids } \\
\text { (TSD) }\end{array}$ & 50200 & 40580 & 26200 & 17,480 & 20 & 33.28 \\
\hline
\end{tabular}

Table 1: Chemical parameters of feed water after natural filtration

Note: The pressure applied must overcome the natural osmotic pressure. Eg. 600-1200 psi of pressure must be used for seawater, as it has a natural osmotic pressure of 390 psi.

Note: All the data mentioned in the table1 is as per the natural osmotic pressure.

Sea water's conductivity is one million times higher than that of deionized water. High quality deionized water has a conductivity of about $5.5 \mu \mathrm{S} / \mathrm{m}$.

\subsection{Reduction percentage of desalinated seawater composition}

$>$ Reduction in $\mathrm{pH}: 95.07 \%$

$>$ Conductivity of seawater was out of range.

$>$ Reduction in chloride ion concentration: $28.19 \%$

$>$ Reduction in sodium ion concentration: $95.1 \%$

$>$ Reduction in TDS (total dissolved solids): $20 \%$

$>$ Reduction in Hardness: $8 \%$

$>$ Reduction in Sulphate: $71.30 \%$

$>$ Reduction in iron: $100 \%$

\subsubsection{Reduction percentage of desalinated brackish water composition}

$>$ Reduction in $\mathrm{pH}: 92.1 \%$

$>$ Reduction in conductivity: $1.5 \%$

$>$ Reduction in chloride ion concentration: $9.6 \%$

$>$ Reduction in sodium ion concentration: $94.98 \%$

$>$ Reduction in TDS (total dissolved salts): $33.28 \%$

$>$ Reduction in Hardness: $11.42 \%$

$>$ Reduction in Sulphate: $67.36 \%$

$>$ Reduction in iron: $100 \%$

\section{Conclusion}

The present obtained results will lead to concentrate on the research over desalination process by using locally available natural filters which is a ecofriendly, cost effective technique and can be easily afforded by common people.
As per the results obtained from prototype1 of seawater, there is $60 \%$ reduction in chloride and $75 \%$ reduction in sodium; this is mainly due to the usage of activated carbon charcoal as the filter media. Better result can be obtained if proper care is taken while conducting the experiments (Coconut shell charcoal might be prepared by heating half splitted coconut shell at a temperature of $900{ }^{\circ} \mathrm{C}$ for 4 hours using a muffle furnace for better results).

1. It is also observed through experiments that there is $100 \%$ reduction in iron, $53 \%$ reduction in sulphate, $20 \%$ reduction in total dissolved solids and $12 \%$ reduction in hardness which clearly indicates that the selected filter medias those are activated carbon charcoal, sand, laterites can be used as the filter medias for future experiments on desalination using natural filters.

2. As per the results obtained there is $100 \%$ reduction in iron, hence it clearly proved that the coconut shell charcoal acts as a purifying agent to remove the iron content.

3. The appreciable result of other composition of feed water such as chloride, sodium, total dissolved solids, sulphate and hardness could not be obtained due to following limitations.

We can overcome those limitations by taking proper care while conducting the experiment and by considering the following points:

Coconut shell charcoal should have been prepared by heating half splitted coconut shell at a temperature of $900{ }^{\circ} \mathrm{C}$ for 4 hours using a muffle furnace for better results.

The prototype should be designed in large scale (as it provides large amount of surface area and minimize the rate of filtration in the prototype) 


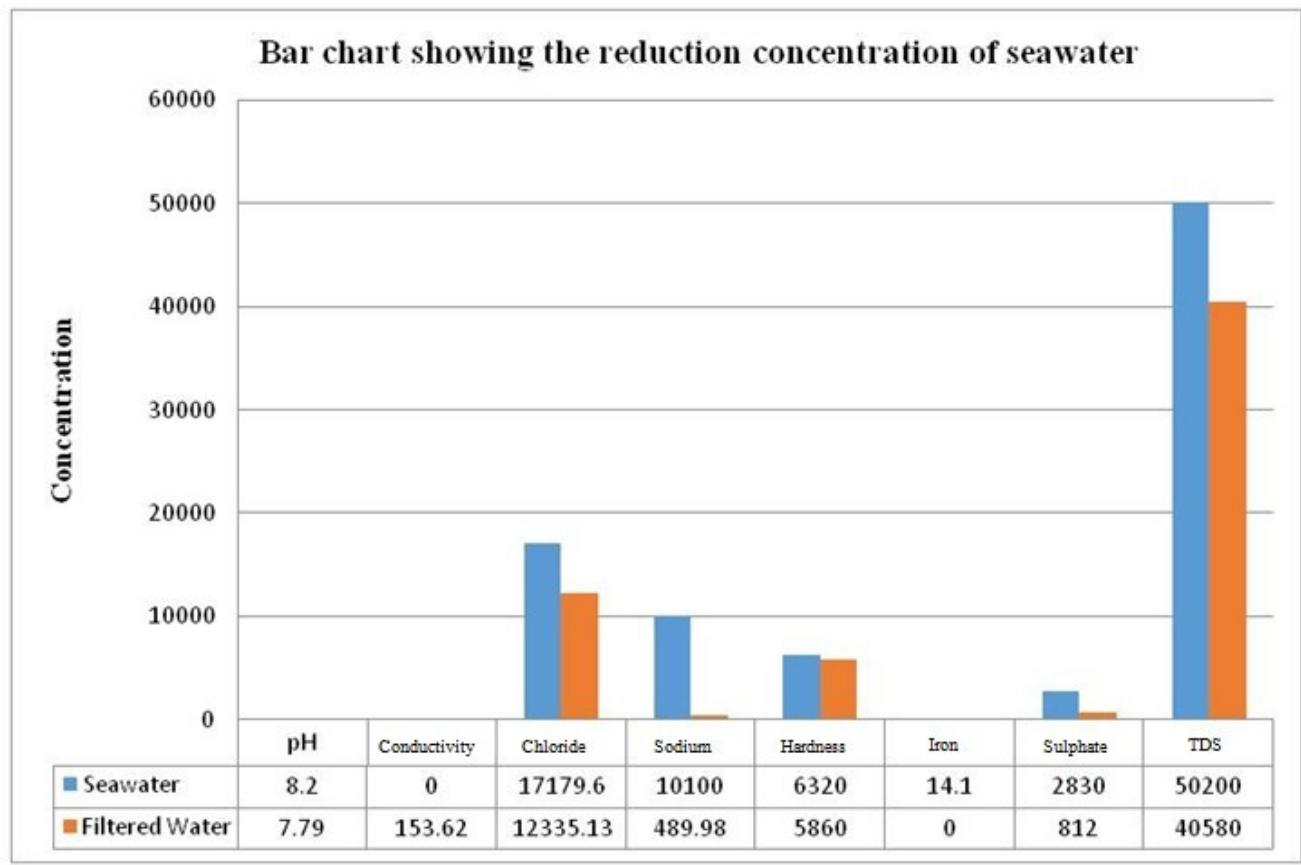

Fig. 4 Bar chart representing the reduction concentration of seawater

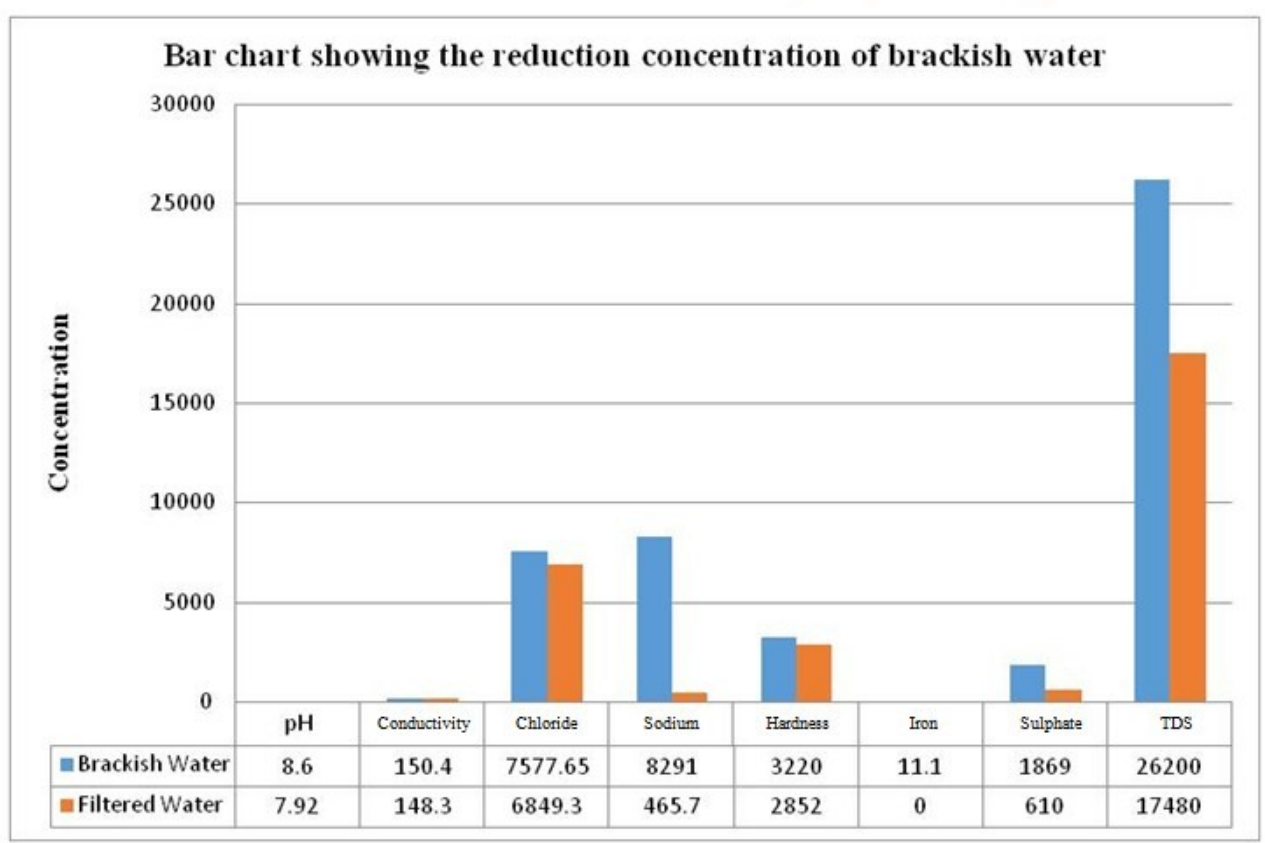

Fig. 5 Bar chart representing the reduction concentration of brackish water

\section{References}

1. Addams, L., Boccaletti, G., Kerlin, M. \& Stuchtey, M. Charting our Water Future: Economic Frameworks to Inform DecisionMaking (2030 Water Resources Group, 2009).

2. A. Q. Jakhrani, S. R. Samo, Habibur Rahman Sobuz, Md. Alhaz Uddin, M. J. Ahsan and Noor Md. Sadiqul Hasan, "Assessment of Dissolved Salts Concentration of Seawater in the Vicinity of Karachi" International Journal of Structural and Civil Engineering, ISSN : 2277-7032, Volume 1 Issue 2, February 2012.
3. Buros, O. K. (2000): "The ABCs of Desalting", International Desalination Association.

4. Binnie, C. Kimber, M. and G. Smethhurst. 2002. Basic Water Treatment, 3rd Edition. Thomas Telford Ltd., London.

5. Clayton, R. (2011): A Review of Current Knowledge Desalination for Water Supply. Bucks: Foundation for Water Research. URL [Accessed: 05.03.2012]. 
6. Desalination, Existing facilities and facilities under construction. Wikipedia: the free encyclopedia. Accessed May 29, 2010. http://en.wikipedia.org/wiki/Desalination.

7. Desalinize. Definition from Answers.com, Accessed May 29, 2010. http://www.answers.com/topic/desalinize.

8. Directorate of Economics and Statistics (Government of Karnataka) (2005). Area, Population, Membership, Revenue, Expenditure \& Employment by Municipalities, Karnataka, 20002001. (PDF). National Informatics Centre (Karnataka State). Retrieved 26 July 2008.

9. Desalination, Existing facilities and facilities under construction. Wikipedia: the free encyclopedia. Accessed May 29, 2010. http://en.wikipedia.org/wiki/Desalination

10. Drioli, E., Alessandra Criscuoli, and Efrem Curcio. Integrated Membrane Operations for Seawater Desalination. Desalination, 147:77-81, 2002.

11. Hasson, D.; Bendrihem, O. (2006): Modeling Remineralization of Desalinated Water by Limestone Dissolution. In: Elsevier Desalination 190, 189-200. URL [Accessed: 05.03.2012].

12. Karim, B. and Marhaba, T.F.: Using principal component analysis to monitor spatial and temporal changes in water quality. J. of Hazardous Mat. vol. B100, pp.179--195 (2003)

13. Krishna, H. J. (1989): Virgin islands Water Resources Conference, Proc. Editor, University of the Virgin Islands and U.S. Geological Survey.

14. Krishna, H. J. (2004): Introduction to Desalination Technologies. Austin: Texas Water Development Board. URL [Accessed: 05.03.2012].

15. Mechell, J. K.; Lesikar, B. (2010): Desalination Methods for Producing Drinking Water. Austin: Agrilife Communications. URL [Accessed: 05.03.2012].

16. Oklejas, E. et al. (1996): "Improvements in the Economics of Reverse Osmosis through Advanced Pumping and Energy Recovery Technology", Proceedings of the American Desalting Association, Monterey, CA.
17. Rao, T.: Overview of Analytical Methodologies for Sea Water Analysis: Part I-Metals. Critical Reviews in Analy. Chem. (2005)

18. Researchers in Cairo have invented a cheap, simple way to turn seawater into drinking water (Credit: Shutterstock), Source: SciDev.

19. Rice, W., and D.C. Chau. 1997. Freeze Desalination Using Hydraulic Refrigerant Compressors. Desalination, 109:157164; and Hahn, W. J. 1986. Measurements and Control in Freeze-desalination Plants. Desalination, 321-341.

20. Straight Dope (2003): What would happen to you if you drank seawater? Straight Dope Science Advisory Board. Accessed May 29, 2010. http://www.straightdope.com/columns/read/2131/ what-would-happen-to-you-if-you-drank-seawater

21. U.S. Department of the Interior, Bureau of Reclamation, "Desalting Handbook for Planners", 3rd Edition, 2003.

22. USGS Water Science for Schools, Updated March 29, 2010. U. S. Geological Survey, U.S. Department of the Interior. Accessed May 1, 2010.

http://ga.water.usgs.gov/edu/drinkseawater.html

23. Taniguchi, M., Burnett, W. C., Ness, G. D.: Integrated research on subsurface environments in Asian urban areas. Sci. of the Total Environ. vol. 404, no. 2-3, pp. 377--392 (2008)

24. Texas A\&M AgriLife: Texas Water. Texas A\&M University. Water Resources Education. Accessed May 1, 2010. http://texaswater.tamu.edu.

25. Tomaszewska, M: Membrane distillation. Environmental Protection Engineering, 25:37-47; and Hogan, P.A., et al. 1991. Desalination by Solar Heated Membrane Distillation. The Twelfth International Symposium on Desalination and Water Re-Use 2:81-90, 1999.

26. 'Water scarcity challenges to business', written by WFN's co-founder and Supervisory Council Member, Arjen Y. Hoekstra, is published in Nature Climate Change series on 'Water risks in the private sector'.

27. Wikipedia.org, Wikipedia Foundation Inc., Accessed May 1, 2010. (Source of vocabulary definitions with some adaptation.) http://wikipedia.org 